\title{
Robert Stam, leitor de $A$ hora da estrela
}

\section{Robert Stam, a reader of A hora da estrela}

\author{
Luiz Antonio Mousinho Magalhães \\ Departamento de Comunicação, Centro de Comunicação, Turismo e Artes, \\ Universidade Federal da Paraíba (UFPB), João Pessoa, PB, Brasil \\ ORCID: 0000-0002-7730-3195 \\ <luizantoniomousinho@gmail.com>
}

\author{
Como citar este artigo (How to cite this article): \\ MAGALHÃES, Luiz Antonio Mousinho. Robert Stam, leitor de $A$ hora da estrela. Revista Famecos, Porto Alegre, v. \\ 25, n. 3, p. 1-18, setembro, outubro, novembro e dezembro de 2018: ID27910. \\ DOI: http://dx.doi.org/10.15448/1980-3729.2018.3.27910.
}

\section{RESUMO}

Em A literatura através do cinema, Robert Stam aborda a adaptação da novela $A$ hora da estrela, de Clarice Lispector, para o cinema, realizada pela cineasta Suzana Amaral. No texto, o autor indica uma questão crítica recorrente no confronto entre filme e obra literária, que é a exclusão do narrador-personagem Rodrigo S.M. da obra fílmica e de elementos de reflexividade relacionados ao narrador, bem como a relação dessa supressão com as tensões entre cinema narrativo e modernismo artístico. Buscaremos acompanhar o debate teórico e crítico de Stam, um dos mais relevantes teóricos contemporâneos, procurando suplementá-lo na abordagem das duas obras. Tomaremos por apoio a narratologia, com ênfase para categorias como narrador e personagem. Em termos de resultados obtidos, atestamos na leitura de Stam o respeito pela obra cinematográfica percebida em sua autonomia discursiva, bem como certa decepção pelo filme ter aberto mão das experiências de linguagem contidas no texto-fonte.

Palavras-chave: Cinema. Recepção crítica. Ficção e sociedade.

\section{ABSTRACT}

In A literatura através do cinema, Robert Stam discusses Suzana Amaral's filmic adaptation of Clarice Lispector's novel A hora da estrela. Stam indicates a recurring critical issue in the confrontation between the film and literary book, which is the exclusion of the narrator-character Rodrigo S.M. of the movie and elements of reflexivity related to the narrator, as well as the relation of this suppression with the conflicts between narrative cinema and artistic modernism. We follow the theoretical and critical debate of Stam, one of the most relevant contemporary theorists, supplementing his theory in the approach of the two works. We use narratology as support, emphasising categories such as narrator and character. In terms of results, we have noticed that Stam shows us such a respect by the filmic work seen in its discursive autonomy as well a certain deception for the film gived up language experiences from the source-text.

Keywords: Film. Critical reception. Fiction and society.

\section{Introdução}

O teórico Robert Stam, em seu livro A literatura através do cinema, ressalta que um dado importante para os eventos das adaptações é a relação do filme com o modernismo (Stam, 2008, p.30). Lembrando a vastidão do termo realismo, o autor ressalta que o conceito só vai se firmar com viés programático no século 
XIX, por oposiçãoaos modelos românticoe mesmo neoclássico (Stam, 2008, p.25). Sabemos que, com duas linhas de força em termos de diálogo, o gesto modernista em cinema vai por vezes se contrapor à estética hollywoodiana baseada no "ideal não somente de enredos convincentes, coerentes de causa e efeito, que giram em torno de 'conflitos maiores', mas também de personagens motivados e críveis" (Stam, 2008, p.30). Conforme Stam, os "primórdios do cinema coincidem com o auge do projeto verístico conforme sua expressão no romance realista, na peça naturalista (em que os produtores teatrais (...) utilizavam carne verdadeira em cenas de açougue)" (p.33). Já o modernismo

[...] artístico que floresceu nas primeiras décadas do século vinte e que foi institucionalizado como "alto modernismo" após a Segunda Guerra Mundial promoveu uma arte anti-realista, não representativa, caracterizada pela abstração, fragmentação e agressão. Embora o incremento tecnológico do cinema faça-o parecer superficialmente moderno, sua estética dominante herdou as aspirações miméticas do realismo literário do século XIX. (STAM, 2008, p.34).

João Batista de Brito ressalta a crise de representação generalizada das artes tradicionais nas primeiras décadas do século XX e a convivência com o cinema que se firmava nesse contexto. Para o autor, ao invés de acompanhar as vanguardas que se apresentavam, o cinema "preferiu seguir o modelo convencional do romance do século anterior, centrado na estória com começo, meio e fim, e aspirando ser três coisas [...]: ficcional, narrativo e representacional". (Brito, 2006, p.8).

Indicandoessa contraposição entre orealismo dominante eo modernismo cinematográfico, Robert Stam finca a discussão em solo cultural e histórico, mostrando que fora "dos limites ocidentais, o realismo raramente dominou; a reflexividade modernista como reação ao realismo, portanto, dificilmente conseguiria exercer o mesmo poder de escândalo e provocação". (Stam, 2008, p.28). Na Índia, ressalta, vê-se uma estética "menos baseada em personagens coerentes e num enredo linear do que em sutis modulações de sentimento e disposição de ânimo". (Stam, 2008, p.28).

Robert Stam ressalta Dom Quixote e Robinson Crusoé como precursores, respectivamente, de uma linhagem paródica, intertextual e mágica no romance e de uma linhagem realista. (2008, p.15). Correndo por fora dessas duas vertentes centrais, Madame Bovary seria a referência para romances "que empregam narradores problemáticos e autodesmistificadores". E inclui $A$ hora da estrela entre esses romances. (2008, p.18).

Noutro sub-capítulo de $A$ literatura através do cinema, intitulado Narração engendrada: $A$ hora da estrela, Stam aborda a adaptação do livro de Clarice 
Lispector para o cinema (1986), indicando uma questão crítica recorrente no confronto com o texto literário, que é a exclusão do narrador-personagem Rodrigo S.M. da obra fílmica e de elementos de reflexividade relacionados ao narrador, bem como a relação dessa supressão com as tensões entre cinema narrativo e modernismo artístico. Vamos acompanhar o debate teórico de Stam, procurando suplementá-lo na abordagem crítica das duas obras, acrescentando ao corpus, ao final, o contraponto da adaptação para a TV da novela literária de Lispector, no programa Cena aberta (2004), dirigido por Jorge Furtado, produto não referido no texto abordado, mas tendo notícias que o teórico tem discutido o referido programa em seus cursos recentes. Antes disso iremos, no próximo tópico, indicar brevemente alguns aspectos gerais da obra de Clarice, em suas relações com a novela literária $A$ hora da estrela.

\section{Clarice Lispector e A hora da estrela}

Observando em 1943 a estreia de Clarice, Antonio Candido lembrava que a"descoberta do cotidiano é uma aventura sempre possível, e o seu milagre, uma transfiguração que abre caminhos para mundos novos". Ao mesmo tempo, o autor evocava momentos da literatura semelhantes à estreante prosa da autora, no sentido de ressaltar o quanto a literatura pode servir como meio de protestar contra "o hábito, a deformação [...] causada pelos sentidos mecanizados". (Candido, 1970, p.128).

"O único modo de descobrir, era, aliás, reconhecer", é dito na narrativa clariceana (Lispector, 1982, p.297). O lastro do reprimido que retorna, do estranho que foi familiar, é recorrente em sua obra. Nela a linguagem desconstrói muito desse recalcado social. O que não se faz de modo apenas temático. As palavras agem de maneiras diversas: nos textos que se esgarçam em melopeias abarrotadas de sugestões som-sentido, nos traços de estilização e paródia que implodem o uso estereotipado das linguagens, nas focalizações que minam o constructo social no que este falseia. Tem-se isso de várias maneiras, em algumas delas na visão da fome tamanha de crianças, nas vidas maltrapilhas, no mergulho na interioridade do outro social visto em sua perplexidade ante o estar no mundo (caso da personagem Macabéa) e, sobretudo, no farrapo de alma do imaginário e do cotidiano de classe média.

As pessoas precisam contar a história de suas vidas. Uma das personagens da autora estanca perplexa, quando vê o taxista ligar o rádio e ser emitida a informação de que o bacalhau produz mil óvulos por ano: "Não soube deduzir nada com essa frase, ela que estava precisando de um destino". (Lispector, 1988, p. 157). Destino perdido no emaranhado de signos e informações que se dispersam soltos, longe da experiência. E como não lembrar aqui da angústia 
da personagem de $A$ hora da estrela ante as informações fragmentadas da Rádio Relógio.

Esse destino é alcançado nos instantes em que os personagens se reencontram consigo mesmos, resgatando seu lastro de passado perdido na percepção cegada pela rotina. E"se em um instante se nasce, e se morre em um instante, um instante é bastante para a vida inteira", como será dito em A maçã no escuro (Lispector, 1982, p.110), e será intuitivamente buscado no gesto de Rodrigo S.M. de resgatar a si mesmo ao tentar criar Macabéa. Como assinala Nádia Gotlib, os personagens clariceanos em sua grande maioria pertencem à media burguesia e são vistos em meio às relações familiares num embate "na tentativa de escapar desses laços institucionalizados, cerceadores da livre manifestação de uma identidade mais íntima e mais autêntica, sob os impulsos da paixão, entendida aqui [...] como uma conjunção paradoxal entre dor e prazer". (Gotlib, 1998, p.162).

Observando as personagens femininas da escritora, Lígia Chiappini assinala que, embora aparentemente conformadas à rotina burguesa, tais personagens "sempre correm o risco de subitamente, deparar com o sem sentido de suas vidas, o que se dá sobretudo quando se defrontam com os mais carentes (pobres ou doentes) na cidade" (Chiappini, 1996, p.62). Aspectos, podemos dizer, no mais das vezes despercebidos em momentos do passado na recepção de Clarice, onde a presença do outro social por vezes passava pouco notado ante o protagonismo dos personagens das classes médias.

Nas personagens desses textos, à técnica de vida faltará o tacto, esse emperramento ferruginoso que faz lembrar às vezes que a engrenagem existe. Mas se a vida fere como a sensação do brilho, as lascas que escapam da escrita são esses aços espelhados que explodem o continuum de uma falsa história. Descontinuam a prosa falseada de um mundo autossuficiente e naturalizado, que conta a eterna história de seus vitoriosos, em tantas narrativas sem fissuras, compactas, fragmentadas no universo clariceano de obras como $A$ hora da estrela, mediadas por um narrador que rompe as continuidades, ao mesmo tempo que sabe ouvir e reconhecer seus limites, deixando falar o outro, expondo as impossibilidades da escrita, do entendimento, de comunhão.

O tema obsedante da morte em Clarice Lispector será um contraponto em relação à vida que segue sem se sentir, à vida que se esvai sem se perceber. Até que a morte-em- vida é vista e se põe a anunciar a vida, como é notado no exílio existencial dos personagens de $A$ hora da estrela, Macabéa e o narrador Rodrigo S.M. Em A hora da estrela, a dedicatória que inicia ou precede a narrativa começa com "Pois que dedico esta coisa aí ano antigo Shumann e sua doce Clara que são hoje ossos, ai de nós" (Lispector, 1990, p.21). E, ao final da narrativa, na 
percepção da finitude, a necessidade de viver, com a "visão da morte apontado para a urgência de viver", para falar com Cleusa Passos (1991, p.173).

O filme de Suzana Amaral é finalizado na cena do atropelamento, onde o sangue brilha na boca de Macabéa e ela morre enquanto sonha com uma adocicada explosão de vida. A alternância de planos da personagem jogada ao chão sujo e, antes, correndo para o abraço do noivo, quando se sabe que ela morrerá, confere um tom paródico à sequência, com o clichêcinematográfico dos amantes em planos alternados e em câmera lenta se dirigindo um ao encontro do outro. Na novela de Clarice Lispector, morre aí Macabéa, mas continua em cena o protagonista Rodrigo S. M. Ele não vai se entregar a lamúrias, nem tampouco ao sentimento de alívio por ter se livrado da personagem. Nem vai ceder à sublimação fácil da vida, em face da presença da morte, particularmente da morte de Macabéa ("- Qual é o peso da luz?") (Lispector, 1990, p.106).

A crueza ante a lembrança da morte pede uma resposta e a reflexão da vida como um processo inevitável e a ser vivido como processo. A morte-emvida de Macabéa e a solidão de Rodrigo S.M. esperam também uma resposta, "resposta que espero que alguém no mundo ma dê. Vós?" (Lispector, 1990, p. 22). Assim o narrador ousa garantir que "o melhor negócio é a ainda o seguinte: não morrer, pois morrer é insuficiente, não me completa, eu que tanto preciso". (1990, p.105), urdindo o início do período com um tom coloquial e trivial para em seguida expor uma afirmação da vida de amplo espectro.

A última palavra do livro, que forma o último parágrafo é Sim: "Não esquecer que por enquanto é tempo de morangos. Sim." (Lispector, 1990, p.106). Isso remete à primeira frase da novela que lembra que "Tudo começou com um sim". Antes dessa afirmação final, porém, o narrador se debate mais uma vez com a visão da morte ("Meu Deus, só agora me lembrei que a gente morre. Mas - mas eu também?!" (1990, p.106). Isso leva a uma visão aguda das contingências da vida e de sua urgência de ser vivida como um processo inevitável e interminável que, enquanto se dá, não pode ceder à não-vida, à vida imersa em morte, exilada. Mas essas questões só são postas, no caso, pelo livro. E restam como um incômodo em parte da recepção crítica, inclusive na do teórico Robert Stam, como buscaremos observar.

É contra as verdades cristalizadas que o narrador clariceano se aloja nas linguagens estereotipadas, rompendo suas imposturas, revelando sua falsa naturalidade, assinalando sua invisibilidade brumosa, saturada de rotina. Ao mesmo tempo, o narrador não se arvora a ser o centro irradiador de certezas, cedendo a voz ao outro, assumindo suas vacilações e limitações. Assim, nos textos clariceanos, há a captação de uma percepção da vivência diária, "tão logo clara e vista, tão logo alterada e obscura", para falar com Roberto Corrêa dos 
Santos. Isso posto de maneira que "a beleza do exposto não parta jamais de um centro único de controle (a autora não legisla)", emergindo de "uma liberdade de escrita e de visão, capaz de facilitar a que as configurações mentais produzidas pelas personagens possam por si mesmas expressar-se" (SANTOS, 1991, p.5).

A impossibilidade de atingir o outro é colocada em Clarice, em vários momentos, de maneira veemente e excruciante --"a outra pessoa é um enigma e seus olhos são de estátua - cegos" (Lispector, 1984, p.9). Assim também está na fatura de $A$ hora da estrela, em um narrador que vacila e assume a impossibilidade de expressão e os abismos existenciais e de classe presentes entre ele e a personagem que vai desenhando, movido pela intuição, pela tentativa de sondagem, entre a dúvida e a comunhão que partilha por certo sentido de exílio existencial que vê em si, que percebe em sua personagem.

A problemática relação existencial, social, representacional entre o narrador e sua criatura somem do enredo e da economia narrativa do filme A hora da estrela, de Suzana Amaral. Vamos procurar ver como o crítico e teórico Robert Stam, teórico do cinema e da cultura, bakhtiniano, brasilianista e estudioso do fenômeno da adaptação, lê essas alterações, configuradas em termos de redução, no filme de Suzana Amaral. Vamos rastrear sua perspectiva crítica, buscando observar e debater sua fala ao mesmo tempo em que procuraremos entender aspectos das duas obras e do diálogo entre elas. Melhor, das três, pois incluiremos na conversa obra não abordada por Stam, a adaptação televisiva de Clarice, dirigida por Jorge Furtado.

\section{Stam, leitor de A hora da estrela}

Em vários de seus livros, artigos e ensaios (2003, 2006, 2008), Robert Stam assinala o erro de se adotar a questão da fidelidade como princípio metodológico na fruição das adaptações, pela diferença de raiz na passagem de um suporte a outro e da percepção de todos os textos como sendo informados por fortes relações intertextuais e dialógicas (Stam, 2008, p.21). O autor assinala que, se infidelidade é um tropo inadequado para o processo, a teoria da adaptação tem um arsenal de tropos e termos para lidar adequadamente com o assunto: "tradução, realização, leitura, crítica, dialogização, canibalização, transmutação, transfiguração, encarnação, transmogrificação, transcodificação, desenho, reescrita, detournement" (2008, p.21). Nisso, assume posição contemporânea vastamente referendada pela crítica acadêmica (Azeredo, 2013; Courseil, 2009; Hutcheon, 2011; Xavier, 2003, para citar alguns). Fica então, como assinala Stam, a noção de adaptação como leitura e sem pretensão de corporificar uma palavra anterior, se concentrando na compreensão dos textos e do diálogo com o texto- 
fonte, adaptação "não como ressuscitação de palavra original, mas como volta num processo dialógico em andamento" (Stam, 2008, p.21).

No entanto, Stam, levando em conta o ponto de vista da recepção, assinala a noção de fidelidade com certo viés de pertinência, pela decepção por parte do leitor/ espectador ao não ver serem captadas características centrais do texto-fonte em seus aspectos temáticos, narrativos e estéticos.

\begin{abstract}
Ao adotarmos uma abordagem ampla, intertextual, em vez de uma postura restrita, discriminatória, não abandonamos com isso as noções de julgamento e avaliação. Mas a nossa discussão será menos moralista, menos comprometida com hierarquias não aceitas. Ainda podemos falar de adaptações bem sucedida ou não, mas agora orientados não por noções rudimentares de fidelidade, e sim pela atenção dada a respostas dialógicas específicas, a leituras, críticas, interpretações e reescritas de romances-fonte, em análises que invariavelmente levam em consideração as inevitáveis lacunas e transformações para mídias e materiais de expressão muito diferentes (STAM, 2008, p. 22).
\end{abstract}

Aqui perceberíamos $A$ hora da estrela e sua adaptação para o cinema, com as possibilidades construídas na relação entre texto-fonte e filme, e em seus aspectos problemáticos, uma relação que abre várias perspectivas de debate crítico e teórico bem explorados por Stam no texto de abordagem da adaptação incluído em Aliteratura através do cinema. Oque setraduz no respeito àautonomia demonstrado na abordagem da obra que adapta, respeito vindo ao lado de certo desconforto perante opções tradutórias que restringem soluções estéticas do texto-fontenoqueestasproblematizamalinguagemeasformasderepresentação. Contradição na abordagem para a qual o autor não busca síntese, deixando em alguns momentos os diálogos entre posições díspares polifonicamente presentes na superfície da abordagem crítica, como veremos adiante.

De saída Robert Stam caracteriza a escritura de Clarice Lispector em sua filiação à "tradição reflexiva de Cervantes, Fielding, Sterne e Machado de Assis", com um narrador que "dá ênfase às escolhas envolvidas na escrita". Como Laurence Sterne, que "constantemente lamenta os aborrecimentos diários que o desviam de sua escrita, o narrador se queixa de que sua cozinheira jogou fora três páginas de seu manuscrito e que a agora ele é obrigado a lembrar do conteúdo delas" (Stam, 2008, p.322). Ele não chega a citar, mas se refere ao trecho onde é dito que "o que se segue é apenas uma tentativa de reproduzir três páginas que escrevi e que a minha cozinheira, vendo-as soltas, jogou no lixo para o meu desespero" (Lispector, 1990, p.48), um dos vários momentos da obra literária onde os processos de escrita são encenados. 
Stam assinala, na introdução teórica de $A$ literatura através do cinema, o quanto a tensão entre magia e realismo, reflexividade e ilusionismo alimenta a arte. Na novela $A$ hora da estrela, vê-se o embate entre um esforço realista declarado pelo narrador-personagem ("história exterior e explícita") e um proceder criativo que se afasta desse viés ou que se alterna com o mesmo, ao contrário das outras narrativas longas da escritora, de rala diegese e muita ênfase nos processos introspectivos e reflexivos. Mas é "que de repente o figurativo me fascinou: crio a ação humana e estremeço. Também quero o figurativo como um pintor que só pintasse cores abstratas quisesse mostrar que o fazia por gosto, e não por não saber desenhar". Já para "desenhar a moça" irá se cercar de cuidados alimentares e evitações, de futebol, sexo e leituras -- "para não contaminar de luxo minha linguagem", cuidados que tomará no "cubículo onde me instalei e onde tenho a veleidade de ver o mundo" (Lispector, 1990, p.37). Esforço especular que não abrirá mão do instrumento de expressão, a palavra, frequentemente dramatizada reflexivamente ao longo de todo narrativa: "Mas sabendo antes para nunca esquecer que a palavra é fruto da palavra. A palavra tem que se aparecer com a palavra. Atingi-la é o meu primeiro dever para comigo" (Lispector, p.34).

Esse trânsito entre uma expressa vontade realista e o desvelar a falácia dessa possibilidade estão presentes durante toda a narrativa literária e são escamoteados do filme de Suzana Amaral, na percepção de Robert Stam. Ele observa que o filme não tem um narrador expresso e sua narrativa não é reflexiva, ao contrário do livro. "Ao eliminar o narrador, que é o lugar da reflexividade no romance, Amaral transfere a ênfase da mediação autoconsciente para o realismo e a exterioridade" (Stam, 2008, p.322-23).

Stam problematiza o estatuto do narrador em Clarice, antes de pensar suas transformações na obra cinematográfica. No texto Narração engendrada: A hora da estrela, principia tratando da equivocidade de gênero do narrador da novela, após indicar filiações onde se apresenta uma presença de atitudes típicas masculinas. Stam lembra a "Dedicatória do autor (na verdade Clarice Lispector)" (como está na obra) que abre o livro. Mas o narrador que se anuncia na obra é masculino.

O narrador do romance tem a hiperconsciência que falta à própria Macabéa. Mas a narração do romance também é genérica e, de alguma maneira, bifurca-se em linhas genéricas. A dedicatória deixa entrever que o "verdadeiro" autor/narrador do livro é Clarice Lispector; no entanto, o narrador S.M. é supostamente masculino, mesmo que nunca estejamos totalmente convencidos deste caso de travestismo narrativo. O narrador, somos informados, tem que ser um homem porque uma mulher choraria diante da situação 
da heroína. Através deste recurso de distanciamento, o machismo construído pelo narrador, para Lispector, mantém uma distância segura, supostamente "masculina" (Stam, 2008, p.320).

A problematização quanto ao gênero (nos dois sentidos), devido à pletora de traços autobiográficos presentes na novela, também é posta por Roberto Corrêa dos Santos, observando a obra e sua adaptação cinematográfica

A hora da estrela, a obra em papel, expõe-se como testemunho ficcional não apenas da vida das personagens ali contidas, mas, digase de modo cru, da própria vida da escritora Clarice, desenhada nessa espécie particular, e raríssima, de autobiografia imaginária e literária. Egografia do escritor, de sua atividade, de suas dúvidas, de seu modo de produzir, de sua relação com a literatura (Santos, 2007, p.2).

As tentativas desse narrador de aproximação da diferença, o seu mudar de hábitos e modos de agir na vida, de roupas, de rotina são encenados na obra literária. Ao mesmo temo, são assumidas as distâncias de posição social, desvelados os lugares de fala, as vozes que se acercam da narração, tomando a expressão aqui no sentido mesmo de instância narrativa nos termos propostos por Gérard Genette (s/d, p.29). E, como assinala Stam, a questão "da diferença de classe entre o narrador e o personagem em $A$ hora da estrela é transposta para uma outra ordem de discrepância que é, por um lado, a das diferenças do poder entre autor e personagem, e, por outro lado, entre narrador e personagem" (Stam, 2008, p.321).

E aqui, num dos lances de visada bakhtiniana do texto, Stam faz uma alusão à percepção de autores autoritários que usam seus personagens como porta-vozes de seus interesses. Assim toca no coração de uma das linhas-deforça do texto clariceano, que é a recusa de um entendimento hierarquizado, didático e em transparência em relação à personagem Macabéa, além do afastamento de um gesto de colocá-la, bem como a qualquer personagem do livro, como símbolo de salvação coletiva.

Vemos aqui outro momento em que as reflexões do teórico e crítico podem ser iluminadoras para o entendimento de nuances de narrativas como a que estamos procurando debater, no caso em formulações teóricocríticas construídas em parceria com Ella Shohat. Remetendo a questões de representação no cinema norte-americano hegemônico, discutidas em dado momento do livro Crítica da imagem eurocêntrica, de Ella Shohat e Robert Stam, podemos ver nesse gesto esteticamente construído em $A$ hora da estrela a recusa de idealização e redenção individual (Shohat; Stam, p. 290) (que seria consoladora e apaziguadora) dirigida a uma situação social para a qual, diríamos, não há saída, nem resposta --"resposta esta que espero que alguém no mundo ma dê. Vós?" $\mathrm{E}$ 
aqui repetimos a provocação do narrador que se assina Clarice Lispector no início da novela literária (Lispector, 1990, p. 22). Ao nosso ver, assim evita-se na obra o perigo de se fixar e isolar "imagens positivas" que desenhem certo essencialismo de classe (Shohat; Stam, p. 289). Dessa maneira, se negando a "personalizar e moralizar questões essencialmente políticas" (Shohat; Stam, 2006 p. 293).

Podemosretomarafala deStamsobreAhoradaestrela,emLiteraturaatravés do cinema, onde ele dá por falta do narrador-personagem e da reflexividade. Antes, vale assinalar que há uma série de acréscimos na diegese no sentido de dar expansão a personagens secundários, como as relações com as colegas de quarto de Macabéa ou sua relação com o chefe no trabalho, ou mesmo na criação de falas para Olímpico. Isso frequentemente é feito com transformação do discurso indireto do narrador em discurso direto desdobrado na boca dos personagens, ampliando também a relação de triângulo amoroso com Glória, ou seja, pela adição de falas e eventos narrativos não presentes na novela.

Esses movimentos vêm, com frequência, no sentido de enxertar enredo, numa narrativa onde, na linha clariceana, há mais investimento no sondar a repercussão dos fatos nos indivíduos do que no perseguir os fatos em si. Porém, não poderíamos dizer que o filme de Suzana Amaral descarta a sondagem do sentimento interiorizado da personagem, constituinte da novela literária e da filiação narrativa a qual pertence. $O$ trabalho com o primeiro plano sobre o rosto da personagem Macabéa captando seu desconcerto e seu desejo perante a existência, sua relação com o espelho em interface com a trilha sonora melancólica e tensa, o uso de planos abertos (ou inclinados) nos encontros dela com Olímpico, ampliando o desequilíbrio entre os personagens, são dados que vão escavando o lírico, o sentimento interiorizado e o traduzindo eficazmente em linguagem audiovisual, com rendimento estético específico e próprio.

O sentido de deserção e solidão também é bem trabalhado na manipulação do espaço narrativo, em determinadas cenas e sequências. Na obra cinematográfica, a trama se transfere da cidade do Rio de Janeiro para a cidade de São Paulo, centro urbano de uma aspereza de grande cidade mais visível. Esse dado, ligado a questões de produção, é potencializado no tratamento espacial, onde são vistas paisagens desoladas e solitárias, típicas de certos locais de grandes metrópoles em dias de feriado, servindo como fator de ampliação da solidão dos personagens. A forma como eles se movimentam - ou se imobilizam -- em meio a tais espaços aguça a visão de seus destinos de deserdados, num trabalho cuidadoso com a planificação e a mise-en-scène. Alguns planos gerais, por exemplo, levam ao limite o sentido de desolamento.

A sequência em que os dois, Macabéa e Olímpico, caminham e discutem numa praça deserta, vista do alto, rumo ao ponto de ônibus, também deserto, 
reforça esse sentido de solidão e perdição. Em outras sequências, eles conversam sob uma via expressa, subjugados sob sua estrutura gigantesca de concreto, inacessível aos dois. Vale notar ainda que o elevado é formado por duas vias que se bifurcam, antecipando a inevitável separação dos personagens. Podemos identificar também, conforme assinala Afonso Barbosa, certa ativação metalinguística nos diálogos de Macabéa e Olímpico, nas indagações a respeito do léxico e da forma de escrever, bem como do significado das palavras escutadas na Rádio Relógio (Barbosa; Mousinho, 2012, p.46).

Afora isso, essas soluções tradutórias que nos parecem felizes esteticamente, não deixa de ser incontornável o desconforto com a supressão do narrador e da reflexividade por parte de vários leitores das duas obras e isso se faz presente na leitura de Stam. Ele destaca depoimento à imprensa de Suzana Amaral dizendo que a metalinguagem não funciona em filmes, que o público não entenderia. Stam destaca ainda fala onde a cineasta diz que "eu eliminei o narrador porque, no meu entender, eu era o narrador" (Amaral citada por Stam, 2008, p.323). Aqui percebemos que a cineasta embaralha uma categoria textual e seu papel como arregimentadora, porquanto diretora, dos artefatos de manipulação do discurso cinematográfico. Temos então a velha confusão teórica, como assinala Gérard Genette, onde "identifica-se a instância narrativa com a instância de 'escrita', o narrador com o autor" (Genette, s/d, p.212). Vale ressaltar a diferença de estatuto ontológico colocada vastamente pela narratologia entre autor e narrador, levando-se em conta que "se o autor corresponde a uma entidade real e empírica, o narrador será entendido fundamentalmente como autor textual, entidade fictícia a quem, no cenário da ficção, cabe a tarefa de enunciar o discurso, como protagonista da comunicação narrativa" (Reis; Lopes, 1988, p.61).

Robert Stam rebate a argumentação de Suzana Amaral quanto à recepção, assinalando como vários filmes audaciosos quanto à estruturação de linguagem, incluindo a reflexividade, foram bem recebidos pelo público no Brasil. "Audaciosos, provocantes e até vanguardistas como O bandido da Luz vermelha" ou que usam o mise-en-abyme como Amuleto de Ogum e Tenda dos milagres (Stam, 2008, p.324). Aqui Stam responde mesmo ao conceito citado por Suzana Amaral, ao alegar a incomunicabilidade do uso de tal recurso (a construção em abismo) e sua opção de "ir direto ao ponto" (Amaral) citada por Stam, 2008, p.323), ou seja, investindo no enredo. Como ressalta Stam, transferindo "a ênfase da mediação autoconsciente para o realismo e a exterioridade" (2008, p.322).

Nas escolhas de Amaral, Stam vê o procedimento padrão na adaptação de muitas obras reflexivas: 


\begin{abstract}
Para Amaral, a lógica cinematográfica pressupõe uma recusa da reflexividade, descartada como "estática" e "ruído" supérfluos que nos distraem daquilo que realmente importa, a história. Nesse sentido, Suzana Amaral fez o que muitos adaptadores de romances reflexivos fizeram. Ela suprimiu o modernismo do original em favor da apresentação da história em si, sem rodeios, imaginada como algo 'por trás' de todo artifício autoconsciente. (Stam, 2008, p.324).
\end{abstract}

O autor ressalta que no filme não há um chamar a atenção para a câmera nem um adiar a apresentação da personagem, ela que aparece já no primeiro momento da obra. Ele ressalta que destaca esses pontos sem pretensão de dizer que o filme seria melhor se fosse reflexivo e afirmando ser o filme "bom como é", mas no caso está ocupado em apontar a opção da obra "pelo realismo e pela transparência". Reconhece que "qualquer romance apresenta uma densa rede de indícios informativos, disponibilizados ao diretor, que pode utilizá-los ou ignorá-los". (Stam, 2008, p.324).

Por outro lado, admite razões econômicas para opção pela dispensa da reflexibilidade. Após, no momento anterior aludido, destacar os fenômenos de comunicabilidade de filmes brasileiros dotados de efeitos de estranhamento e reflexividade, reconhece a opção do público em sua maioria pelo cinema narrativo dominante, onde o chamar a atenção para os procedimentos de construção da obra frequentemente não são bem aceitos. Assim, lembra que o público do cinema "dominante está a costumado a se deixar levar pela história, ressentindo a interrupção, a desconstrução e o questionamento da forma como acontece no romance de Lispector" (Stam, 2008, p.324).

Após debater a caracterização de Macabéa como sendo fortemente corporal, mas vista numa dificuldade da personagem de lidar com o próprio corpo (numa leitura muita exata), indica um dado importante nas investigações das relações ficção e sociedade na obra. Stam vê um distensionamento da diferença e da realidade de classe na eliminação do narrador em seu embate com a personagem, tendendo a diminuir nos espectadores a percepção das diferenças sociais.

Essas diferenças sociais são agora deslocadas para outro registro entre os personagens - onde o leque social é muito mais fechado. Assim sendo, num outro sentido o filme poderá ser visto como mais elitista, já que as reconhecidas diferenças sociais entre o personagem e o narrador são veiculados de maneira pseudo-objetiva. A narração "impessoal" do filme exibe a diferença social de Macabéa ao revelar que ela não consegue atender às normas burguesas de comportamento socialmente correto, normas que não precisam ser formuladas porque elas foram internalizadas pelo público de classe 
média que julga os personagens de acordo com elas (Stam, 2008, p. 326).

Por essa percepção, fica evidenciado um dos procedimentos do filme de construção do riso, que termina, de fato, sendo hierarquizador, submetendo a personagem à condição de alvo de escárnio por não se adequar as normas de relação interpessoal, de trânsito social, de higiene. Na narrativa literária, a tradução do desconforto da personagem quanto ao estar no mundo e em meio às relações sociais, a sondagem de seu sentimento interiorizado, sua espessura existencial vinda a par com sua leseira, sua eventual burrice, seu sem jeito, "sua condição mofina, jururu, panema" (Veloso, 1984), não a inferiorizam nem arrancam risos no viés indicado, além de servirem de impedimento a uma adesão melodramática ou de apropriação político-partidária, estética e historicamente falseadoras. No narrador do livro vê-se um sentido partilhado de exílio e margem, a revelação do seu igual desajeito na existência e na vida em sociedade e as indagações éticas que se acumulam sobre o seu proceder na representação do outro de classe.

Roberto Corrêa dos Santos, percebe nas certezas do narrador do filme, ou na sua ausência de vacilação, um suturar a dúvida e suspender o "vibrátil estado ético" que sustenta as páginas de $A$ hora da estrela e, diríamos nós, seu vertiginoso trânsito entre vida, morte e morte-em-vida de seus personagens Macabéa e Rodrigo S.M. No filme,

o fato constitui o motor; portanto impõe ser muitíssimo bem cuidado, dando-se ao detalhe. O filme visa a contar. O filme crê na história e na sequência. Para realizar-se, agarra-se ao acontecimento como o essencial nutriente. Entre acolher o mais livre imaginário, o absoluto ímã da linguagem e aceitar o direito ou a condição de operar com a substância cotidiana, tendo à frente a Vida (suas faces) e a impossibilidade do Entendimento (e toda a tensão daí resultante), o cinema de Suzana - esse - apaga o conflito, arruma os rasgos do disperso, dilui, amortece, amacia, desfaz a embriaguez, e cuida (Santos, 2007, p.2).

Nesse cuidar, resta a opção recorrente pelo narrador impessoal, conforme assinala Robert Stam, concluindo sua leitura sobre a filiação da adaptação a uma das linhas-de-força possíveis e recorrentes nos processos adaptativos.

Avançando em direção à década atual e percebendo incorporações na ficção televisiva de experiências do cinema de vanguarda do passado, temos uma nova adaptação de $A$ hora da estrela, de autoria de Jorge Furtado, Guel Arraes e Regina Casé, dentro da série de quatro adaptações da série Cena Aberta, 
produzido pela Casa de Cinema de Porto Alegre e Central Globo de Produção e veiculada pela Rede Globo.

Revelando os bastidores de produção, apontando abertamente as manipulações de tempo, espaço e personagem, etc, Cena Aberta parece se valer de conquistas metalinguísticas instauradas pela televisão brasileira nos anos 80 , em programas e horários específicos, inspirados em procedimentos de vanguardas no cinema de décadas anteriores, mas correndo em faixa própria, dentro de um ambiente de consumo por grandes audiências (mesmo que fora do chamado horário nobre). E com feições próprias também na mescla entre ficção e narrativa telejornalística, incorporando-se fortemente o gênero jornalístico entrevista à narrativa.

O programa se constrói de cenas de ensaios, de representações do texto, depoimentos da vida pessoal de várias candidatas amadoras que tentam interpretar Macabéa, conduzidas por Regina Casé (que fazalgumas personagens, inclusive ela mesma e Glória). A exibição editada de momentos de construção da personagem, os off e os vários momentos em voz over retirados do texto clariceano e que servem de fio condutor em trechos da narrativa, parecem resgatar dados do narrador da novela literária e da discussão assumida em torno dos meandros do processo mimético. Inclusive de seus impasses, mostrados nas vacilações da direção e das moças várias que representam Macabéa. Elas que titubeiam no instante de entendimento do personagem, nos momentos em que a narrativa oscila, nas várias possibilidades de manipulação, de ordenação e desfecho. Dessa maneira, A hora da estrela do Cena Aberta se faz mais próxima da obra de Clarice Lispector do que o filme de Suzana Amaral, no que toca à presença do narrador-personagem e da reflexividade reclamadas por Robert Stam.

À sua maneira, aqui estão presentes procedimentos metalingüísticos que, ousados e até agressivos no passado, por desconstruírem a mímesis clássica, comparecem ao cinema e à televisão contemporâneos como dados viáveis nas várias possibilidades de representação ficcional. São procedimentos específicos de narrativas de largo consumo e que, ao contrário da novela literária adaptada, não apontam uma crise nas maneiras de representar. Apresentam, sim, procedimentos ampla e intuitivamente percebidos e aceitos pela recepção como possibilidades viáveis e criativas de ativação do jogo de luzes e sombras acenado pela representação ficcional. E que, no caso específico, parecem reativar alguns lances do jogo tenso e sumarento da prosa germinadora que Ihe deu origem.

No caso da obra literária $A$ hora da estrela e também de sua adaptação televisiva, vemos uma marcada investida dialógica e mais do que isso, polifônica, se entendermos, com Diana Barros, o dialogismo como constitutivo de toda 
linguagem e o caráter polifônico como estando presente nos textos que revelam esses diálogos (Barros, 1997, p.35). No texto literário e no Cena aberta, tradição e desconstrução dialogam em copresença manifesta. O livro de Clarice já prevê a virtualidade polifônica recriada pelo programa televisivo para seu contexto, explorando as possibilidades discursivas dos audiovisuais. No caso do texto cuja recepção crítica estamos procurando debater, o ensaio de Robert Stam, o Cena aberta não é um objeto observado.

Em sua recepção crítica da obra literária e do filme, Robert Stam põe em movimento as balizas teóricas que assinalam um olhar amplo, generoso e não hierarquizado sobre estruturas narrativas postas em diálogo. Ao mesmo tempo, situa ambas as obras e os processos adaptativos dentro do escopo mais geral das representações literárias e cinematográficas, experimentando o pulso das oscilações entre realismos e antiilusionismos, colando as obras em diálogo com essas duas tradições bem como com o discurso cinematográfico, situado em suas possibilidades e limites, dentro de determinados ambientes de produção, com suas implicações estéticas, econômicas e políticas. Situa ainda a obra literária como filiada a um terceiro veio, onde assomam "romances que empregam narradores problemáticos e auto desmistificadores" (Stam, 2008, p.18).

Sua abordagem da adaptação de $A$ hora da estrela se equilibra no fio de navalha do respeito ao diálogo e à autonomia das obras, a uma concepção de linguagem e sociedade que não permite hierarquização entre cinema e literatura nem outras subordinações. A dificuldade enfrentada pelo texto talvez seja fazer isso sem abrir mão da avaliação crítica. Nesse equilíbrio difícil - o problema que essa adaptação coloca é enorme --, Stam aponta algumas das fragilidades das concepções de Suzana Amaral, visíveis na obra e nas falas da diretora ao expor as escolhas do filme. Num dos pontos do debate, o texto A narração engendrada vacila, ao indicar os filmes brasileiros que injetaram mudanças na tradição realista e "narrativa", alcançando também boa comunicabilidade com o público. Ao mesmo tempo, o texto logo abaixo reconhece, como vimos, que o desvio do modelo mainstream pode sim provocar um afastamento do público, acostumado a "ver a história seguir".

Fica nas entrelinhas, embora respeitando a obra cinematográfica e sua autonomia ("o filme é bom") certa decepção pelo fato da obra cinematográfica ter aberto mão das experiências de linguagem contidas no texto-fonte, deixando de ousar, de explorar esteticamente o banquete de possibilidades que o discurso cinematográfico dispõe. Stam, conhecedor dos meios, da cultura brasileira e das várias alternativas de diálogo entre as mídias e as expressões artísticas, só pode ambicionar que a emergência de vozes plurais possam ser mobilizadas no 
sentido da potencialização estética das possibilidades expressivas dos textos, bem como de seus gestos reveladores e tensionadores do entorno social.

\section{Referências}

A HORA da estrela. Direção: Suzana Amaral. Roteiro: Suzana Amaral e Alfredo Orós. Intérpretes: Marcélia Cartaxo, José Dumont, Tâmara Taxman. Música: Marcus Vinícius. São Paulo: Assunção Hernandes, 1986. 1 bobina cinematográfica (96 $\mathrm{min})$, son., color., $35 \mathrm{~mm}$.

AZERÊDO, Genilda. Reencenando imagens e palavras: anotações sobre literatura e filmes. João Pessoa: EDUFPB, 2013.

BARROS, Diana Luz Pessoa de (1997). Contribuições de Bakhtin às teorias do discurso. In: BRAIT, Beth (org.). Bakhtin, dialogismo e construção do sentido. Campinas, SP: Editora da Unicamp. p. 27-38.

BORELLI, Olga. Clarice Lispector: esboço para um possível retrato. Rio de Janeiro: Nova Fronteira, 1981.

BRITO, João Batista de. Literatura no cinema: narrativas em conflito. São Paulo: Unimarco, 2006.

CANDIDO, Antonio. No raiar de Clarice Lispector. In: Vários escritos. São Paulo: Duas Cidades, 1970, p.126-131.

CENA aberta: a magia de contar uma história. Produção: Casa de Cinema de Porto Alegre e Rede Globo. Intérpretes: Luís Carlos Vasconcelos e Regina Casé. Episódio As três palavras divinas. Direção: Guel Arraes, Jorge Furtado e Regina Casé. Roteiro Guel Arraes e Jorge Furtado. Música: Banda Metallica. Rio de Janeiro: Globofilmes, 2004. 1 DVD (133 min), son., color.

CHIAPPINI, Ligia. Pelas ruas da cidade uma mulher precisa andar. Revista Literatura e sociedade, n 1, São Paulo: USP/FFLCH, 1996. Disponível em: http://www. revistas.usp.br/ls/article/view/682 Acesso em 21 maio 2017.

CORSEUIL, Anelise Reich. Literatura e cinema. In: BONNICI, Thomas; ZOLIN, Lúcia Osana (Org). Teoria literária: abordagens históricas e tendências contemporâneas. Maringá: Eduem, 2009.

GENETTE, Gérard. 0 discurso da narrativa. Lisboa: Vega Universidade, s/d.

GOTLIB, Nádia. Um fio de voz: histórias de Clarice. In: LISPECTOR, Clarice. A paixão segundo G.H. Paris: Association Archives de la literatura latino-americáine, des Caraibes et africaine du XXe. Siècle; Brasília,: CNPq, 1988.p.161-195.

HUTCHEON, Linda. Uma teoria da adaptação. Florianópolis: Ed. da UFSC, 2011. 
LISPECTOR, Clarice. A hora da estrela. Rio de Janeiro: Francisco Alves, 1990.

LISPECTOR, Clarice. A maçã no escuro. Rio de Janeiro: Nova Fronteira, 1982.

LISPECTOR, Clarice. A paixão segundo G.H. Paris: Association Archives de la literatura latino-americáine, des Caraibes et africaine du XXe. Siècle; Brasília,: CNPq, 1988.

LISPECTOR, Clarice. A via crucis do corpo. Rio de Janeiro: Nova Fronteira, 1984.

PASSOS, Cleusa. Clarice Lispector: os elos da tradição. Revista USP. Junho/ Julho/ agosto 1991, n¹0, p.167-174.

REIS, Carlos; LOPES, Ana Cristina. Dicionário de teoria da narrativa. São Paulo: Ática, 1988.

ROUANET, Sérgio Paulo. Édipo e o anjo: itinerários freudianos em Walter Benjamin. 2a ed. Rio de Janeiro: Edições Tempo Brasileiro, 1990. (Col. Tempo Universitário, 63).

SANTOS, Roberto Corrêa dos. Artes de fiandeira. In: Laços de família. Rio de Janeiro, Francisco Alves, 1991.

SANTOS, Roberto. A hora da estrela: o papel e a tela. Graphos: Revista da pós-graduação em Letras da Universidade Federal da Paraíba. Vol. 9, n.1, 2007/ João Pessoa: 2007. Disponível em: http://periodicos.ufpb.br/index.php/graphos/article/ view/4707 Acesso em: 23 mar. 2017.

STAM, Robert. A literatura através do cinema: Realismo, magia e a arte da adaptação. Trad. Marie-Anne Kremer e Gláucia Renate Gonçalves. Belo Horizonte: EDUFMG, 2008.

STAM, Robert. Introdução à teoria do cinema. Campinas, SP: Papirus, 2003.

STAM, Robert. Teoria e prática da adaptação. Revista Ilha do Desterro. no 51 - Jul-Dez 2006. Florianópolis, Santa Cataria. Disponível em: https://periodicos.ufsc.br/ index.php/desterro/article/view/9775 Acesso em: em 21 de outubro de 2013.

VELOSO, Caetano. A hora da estrela de cinema. In: BETHANIA, Maria. LP A beira e o mar. Rio de Janeiro, Polygrama, 1984.

XAVIER, Ismail. Do texto ao filme: a trama, a cena e a construção. In: PELLEGRINI, Tânia et al. Literatura, cinema, televisão. São Paulo: Editora Senac; São Paulo: Instituto Itaú Cultural, 2003. 
Recebido em: 6/7/2017

Aceito em: 30/10/2017

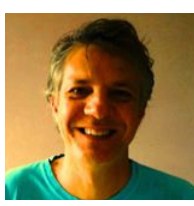

Dados do autor:

Luiz Antonio Mousinho Magalhães | luizantoniomousinho@gmail.com

Universidade Federal da Paraíba (UFPB)

Professor Associado IV do Departamento de Comunicação e da Pós-graduação em Letras

da Universidade Federal da Paraíba. Desenvolve pesquisa junto ao CNPq (PQ)

sobre análise e recepção de ficção audiovisual.

Endereço do autor:

Cidade Universitária, s/n - Castelo Branco III

58051-085 - João Pessoa, Paraíba, Brasil.

Este artigo é licenciado sob forma de uma licença Creative Commons Atribuição 4.0 Internacional (CC-BY). 